\title{
REPRODUCTIVE SEASONALITY, OVIPOSITION AND DEVELOPMENT OF THE NASSARIID WHELK BUCCINANOPS COCHLIDIUM (DILLWYN, 1817) IN PATAGONIA, ARGENTINA
}

\author{
ANDRÉS AVERBUJ ${ }^{1,2}$ AND PABLO E. PENGHASZADEH ${ }^{1}$ \\ ${ }^{1}$ Museo Argentino de Ciencias Naturales, CONICET, Av. Angel Gallardo 470, lab 57, 1405 Capital Federal, Argentina; and \\ ${ }^{2}$ Centro Nacional Patagónico, CONICET, Bvd. Brown 2915, 9120 Puerto Madryn, Chubut, Argentina
}

(Received 26 January 2009; accepted 15 June 2009)

\begin{abstract}
Seasonality of reproduction in Buccinanops cochlidium, including mating, oviposition and embryonic development, was studied within a population in Patagonia. Mating was observed mainly during autumn and winter (March to October). Females carrying egg capsules were found between July and October when water temperature was $10^{\circ} \mathrm{C}$, while development of embryos continued until February (the hatching peak) when water temperature was $18^{\circ} \mathrm{C}$. All egg capsule masses were found attached to the shells of females $80-102 \mathrm{~mm}$ in length. The spawn consisted of 80 to 238 egg capsules, attached to the apertural callus of the shell. Linear regression analysis showed no significant relationship between female size and number of egg capsules. Each egg capsule contained 3100 eggs on average, with a mean egg diameter before cleavage of $227.5 \mu \mathrm{m}$. One to 20 embryos completed their development within each egg capsule by ingesting around 570 nurse eggs. The embryos followed a typical holoblastic spiralian division until gastrulation. During the 'veliger' stage the embryo consumed nurse eggs and formed a large rounded embryo up to $2 \mathrm{~mm}$ in diameter. After shell development the embryos hatched as crawling juveniles of $4.0 \mathrm{~mm}$ shell length through an opening opposite to the capsule stalk. There was an inverse relationship between the mean hatching shell size and the number of embryos per egg capsule. Under laboratory conditions development was completed in four months.
\end{abstract}

\section{INTRODUCTION}

The larval growth of the Neogastropoda includes a period of intracapsular development, after which embryos hatch either as free-swimming larvae or as crawling juveniles (Fretter \& Graham, 1994). The nutritional resources for intracapsular development are provided by several means, including numerous nurse eggs per capsule to be eaten by one or more embryos (adelphophagy) (e.g. Fasciolaria tulipa hollisteri, Penchaszadeh \& Paredes, 1996; Trophon species, Penchaszadeh, 1976), a single large yolk-filled egg $(>800 \mu \mathrm{m})$ in each egg capsule (e.g. Prunum prunum, Penchaszadeh \& Rincón, 1996; Olivancillaria species, Borzone, 1995), and/or the provision of nutrients in the intracapsular fluid (e.g. Buccinum sp., Miloslavich, 1996; Engoniopus unicinctus, Miloslavich, 1999). In the Nassariidae both free larval and direct development occur, as for example in Bullia (Brown, 1982) and Nassarius (Pechenik, 1975) respectively, but neither produces large eggs.

With respect to nurse egg ingestion in neogastropods, Fioroni (1967) suggested several possibilities, including degradation by rotation of the nurse eggs, embryonic mechanical destruction of the eggs and ingestion of particles, and the ingestion of entire nurse eggs.

The genus Buccinanops is widely distributed in shallow waters of the southwestern Atlantic Ocean. Adult snails are medium sized with a fusiform shell, typically inhabiting soft bottoms (Pastorino, 1993; Rios, 1994). Species are gonochoristic with internal fertilization. The production and attachment of egg capsules implies a remarkable reproductive effort. A variable number of triangular to rectangular, flattened and flexible egg capsules are attached to the apertural callus of adult shells

Correspondence: A. Averbuj; e-mail: averbuj@cenpat.edu.ar
(Penchaszadeh, 1971a, b, 1973), which provides both a suitable hard substrate and care of the egg capsules. There is no published evidence that the egg capsules are attached to the shell by the same snail that carries them. Embryos complete their development within the egg capsule by the ingestion of nurse eggs, and then hatch as crawling juveniles through a distal opening (Penchaszadeh, 1971a, b).

In general, intracapsular developmental times vary widely between species depending on the hatching stage and environmental conditions (Miloslavich, 1996). The developmental time for embryos of Buccinanops species is unknown, and there is no published information about size at reproductive maturity or the gonadal cycle.

Buccinanops cochlidium is distributed from Rio de Janeiro in Brazil (as B. gradatum sensu Rios, 1994) to Golfo Nuevo in Argentina. In Patagonia $B$. cochlidium lives in temperate coastal waters on soft bottoms of the subtidal zone, usually at depths between 5 and $15 \mathrm{~m}$. It is the largest species of the genus, reaching $110 \mathrm{~mm}$ in length. A subtle sexual dimorphism is present, with smaller maximum size in males than in females (A. Averbuj, unpubl.). Buccinanops cochlidium is a potential target for local fisheries (Ciocco, 1999), so improved knowledge of its reproductive biology is required before sustainable fisheries policies are developed.

Penchaszadeh's previous work on B. cochlidium was carried out using four museum specimens from which the egg capsules and the late stage embryos were described (as B. gradatum; Penchaszadeh, 1971b, 1973). Commonly one embryo hatches per egg capsule in Buccinanops species, but B. cochlidium is the exception, with four to 10 embryos ingesting thousands of nurse eggs and hatching as crawling juveniles (Penchaszadeh, $1971 \mathrm{~b}, 1973)$. The present work is based on two years' sampling of abundant live material. 
In this paper we describe the seasonality of reproduction, mating, oviposition and embryonic development of $B$. cochlidium from Playa Villarino, northern Patagonia. This site represents an opportunity for studying a population that has not suffered the effects of imposex associated with high marine traffic (Penchaszadeh, Averbuj \& Cledón, 2001; Goldberg et al., 2004; Bigatti et al., 2009) or of commercial fishery.

\section{MATERIAL AND METHODS}

Samples and observations were made monthly from December 2004 to November 2007, in Playa Villarino, in Golfo San José $\left(42^{\circ} 25^{\prime} \mathrm{S}, 64^{\circ} 31^{\prime} \mathrm{W}\right.$; Fig. 1). Bottom water temperature was obtained daily by an $\mathrm{HOBO}$ underwater data logger placed at the sampling site for the complete period of study.

From December 2004 to November 2006, 20 individuals of Buccinanops cochlidium (representing all sizes) were randomly collected each month. Collection was performed by SCUBA diving on muddy bottoms at depths between 5 and $15 \mathrm{~m}$. Total shell lengths (TSL) were measured with Vernier caliper $0.1 \mathrm{~mm}$ precision) and the wet soft-body mass (WBM) weighed to the nearest $0.1 \mathrm{~g}$. The specimens were dissected immediately and sexed by presence or absence of a vagina and accessory glands.

The study was supplemented by monthly field observations during sampling. The presence of mating individuals and the frequency of copulation were recorded. Monthly observations (without collection of material) were made during the third year of study, to confirm seasonality.

\section{Oviposition}

The proportion of breeding individuals per month was estimated from the number of egg capsule masses and the total number of individuals collected each month. The egg masses were studied fresh; when this was not possible they were fixed in $5 \%$ formalin. Egg capsules were counted in each spawn mass. To study intracapsular development 50 individuals carrying egg masses were selected from the total capture, to represent the complete range of adult shell sizes, and excluding incomplete or damaged egg masses. Five egg capsules were randomly chosen from each of the 50 masses, detached from the shells, measured (total length, maximum width and total pedicle length) and dissected.

\section{Development}

The number of nurse eggs per capsule was counted under a light microscope. The intracapsular egg diameter was

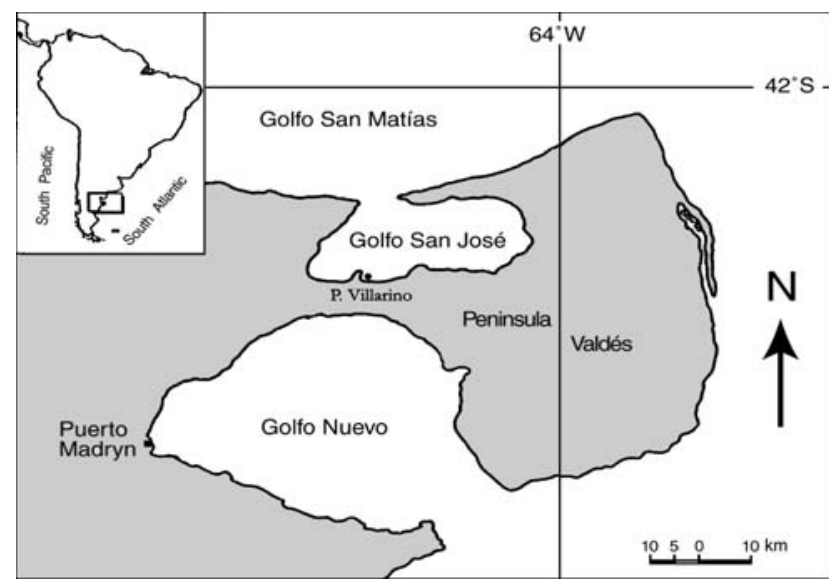

Figure 1. Location of Playa Villarino in Golfo San José, Argentina. measured before cell division; for this purpose 50 eggs were randomly chosen from each female.

Embryos within the egg capsules were classified into one of nine developmental stages: 0, Egg: round, before cell cleavage; 1, Cell Cleavages: embryo with two to eight cells (macromeres and micromeres); 2, Morula: multicellular $(>16)$ roundish embryo without a ciliated velum or other larval structure (this stage is reached at different cell numbers depending on taxon, Van den Biggelaar \& Haszprunar, 2003); 3, Early 'Veliger': ciliated velum, mouth and empty stomach; 4, Ingesting 'Veliger': increasing quantities of nurse eggs inside stomach, with first shell matrix and foot; 5, Late 'Veliger': large embryo with stomach full of eggs, with foot and thin calcified shell; 6, Coiling Embryo: crawling stage, coiled shell, stomach is reduced and velum resorbed; 7, Pre-hatching: white calcified shell, stomach persists as an empty sac external to shell; 8, Hatchling: juvenile is a miniature adult (Table 1).

Total length of the embryos was measured at each of the developmental stages. At the hatching stage, the number of juveniles per capsule was counted and measured in all intact capsules. The mean hatching shell length (MHSL) was calculated. All measurements were made with stereoscopic microscope with a $0.1-\mathrm{mm}$ precision ocular micrometer.

\section{Aquarium observations}

During August 2005 (end of austral winter), four animals carrying egg masses were collected and maintained in separate aquaria. These were the first egg masses to appear in the year and were evidently recently laid (stage 0 ). Salinity was maintained at 35 in concordance with field measurements, temperature ranged between 12 and $14^{\circ} \mathrm{C}$ (spring temperature) and a $12: 12$ h light: dark photoperiod was maintained. The animals moved, fed and buried as observed in the field, but did not mate or lay egg capsules. Each week five egg capsules were detached from each shell and dissected to ascertain the stage of development.

\section{Statistical analysis}

The relation between the TSL of the animal carrying the egg capsules and the number of capsules was evaluated by linear regression analysis. The residuals of a linear regression of WBM on TSL were used to calculate the female body condition (BC) index (Hargitai et al., 2005). Linear regressions of $\mathrm{BC}$ on number of egg capsules, and number of embryos per egg capsule and MHSL were calculated. All tests and statistical analyses were done with Statistica 7.0.

\section{RESULTS}

Bottom water temperature varied between $10^{\circ} \mathrm{C}$ in September (end of austral winter) and $18^{\circ} \mathrm{C}$ in March (late summer) (Fig. 2). Mating was observed in the field from March to October (during decreasing water temperature; Fig. 2) in both years (2005, 2006) (Fig. 2, Table 2). During mating the male was usually buried or semi-buried, surrounding the buried shell of the female with its foot. Male and female shells were positioned side by side, oriented in the same direction (Fig. 3A). The male introduced the flat, elongated penis into the female's mantle cavity to reach the vagina (Fig. 3B). Mating frequency increased before the start of oviposition (July to September). Stored sperm were found in the bursa copulatrix of females captured from March to October (Table 2). 
Table 1. Embryonic intracapsular development of Buccinanops cochlidium.

\begin{tabular}{|c|c|c|c|}
\hline Stage & Description & Mean embryos size $(\mu \mathrm{m})$ & $\begin{array}{l}\text { Time* } \\
\text { (days) }\end{array}$ \\
\hline 0 (Egg) & Round and whitish, before cellular cleavage & $227.5 \pm 13.5(160-280) n=2,500$ & $0-1$ \\
\hline 1 (Cell cleavages) & Embryo with 2-8 macromeres and micromeres & $299.6 \pm 25.3(200-340) n=53$ & $7-10$ \\
\hline 2 (Morula) & Roundish embryo with several cells $(>16)$ & $264.0 \pm 27.4(230-320) n=38$ & $1-3$ \\
\hline 3 (Early ‘veliger') & Embryo with ciliated velum, mouth and empty stomach & $511.3 \pm 132.3(320-800) n=30$ & $5-9$ \\
\hline 4 (Ingesting 'veliger') & Increasing quantities of nurse eggs inside stomach. First shell matrix and foot & $2761.2 \pm 738.5(1,076-5,075) n=88$ & $40-45$ \\
\hline 5 (Late 'veliger') & Large embryo; sac full of eggs, developed foot and thin calcified shell & $2878.3 \pm 531.6(1,800-4,100) n=39$ & $3-7$ \\
\hline 6 (Coilied embryo) & Crawling stage, with coiled shell, stomach is reduced and velum resorbed & $3694.1 \pm 341.3(2,922-4,306) n=54$ & $45-50$ \\
\hline 7 (Pre-hatching) & $\begin{array}{l}\text { Juvenile with white calcified shell, stomach persists as an empty sac at apex } \\
\text { external to shell }\end{array}$ & $3492.9 \pm 437.8(2,768-4,614) n=38$ & $5-10$ \\
\hline 8 (Hatchling) & Juvenile hatches as miniature adult & $4000.0 \pm 620.0(2,400-7,000) n=626$ & $0-1$ \\
\hline
\end{tabular}

Values represent mean size \pm SD and range (brackets). *Developmental time recorded in aquarium; total $=106-135$ days.

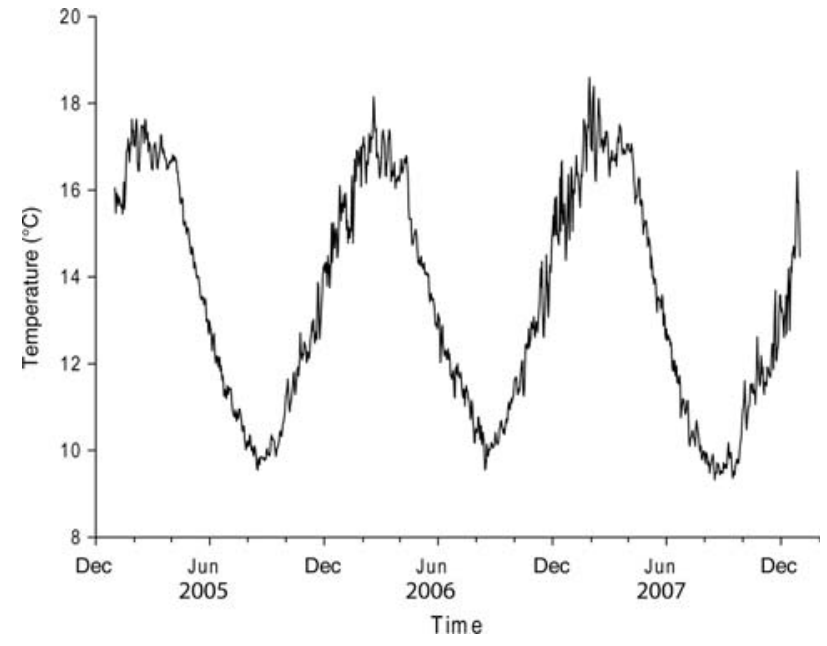

Figure 2. Bottom water temperature (December 2004-January 2008).

Table 2. Mating and oviposition observed in the field, and sperm held in bursa copulatrix, during the period of study of Buccinanops cochlidium.

\begin{tabular}{llll}
\hline Months & Mating & Egg capsules & $\begin{array}{l}\text { Sperm in bursa } \\
\text { copulatrix }\end{array}$ \\
\hline Jan & No & Yes & No \\
Feb & No & Yes & No \\
Mar & Yes & No & Yes \\
Apr & Yes & No & Yes \\
May & Yes & No & Yes \\
Jun & Yes & No & Yes \\
Jul & Yes* & Yes & Yes \\
Aug & Yes* & Yes & Yes \\
Sep & Yes* & Yes & Yes \\
Oct & Yes & Yes & Yes \\
Nov & No & Yes & No \\
Dec & No & Yes & No \\
\hline
\end{tabular}

${ }^{*}$ High frequency.

\section{Oviposition}

All of the 88 adults carrying egg capsules that we examined were females, with a size range between 80 and $102 \mathrm{~mm}$ shell length.

The monthly percentages of females with egg capsules are shown in Figure 4. We found intact egg capsule masses (with eggs and/or living embryos) from July to February (rising water temperature; Fig. 2) in both 2005 and 2006 (Table 2). The number of spawn masses containing recently laid capsules (embryo stages 0,1 ) increased from July to October, and then decreased abruptly in November (Fig. 4). The maximum frequency of egg capsules masses occurred from October to February. By March all females were free of egg masses or possessed only residual empty capsules. The same seasonal pattern was confirmed by field observations made during 2007.

Egg masses consisted of $142.2 \pm 30.0 \mathrm{egg}$ capsules (mean \pm SD) (range $=80-238 ; n=50$ ) attached to the shell by means of short stalks measuring $1.4 \pm 0.5 \mathrm{~mm}(n=250)$. Egg capsules were elongated and flattened, and triangular to rectangular in shape, measuring $14.3 \pm 1.2 \mathrm{~mm}(n=250$; range $11.7-$ $17.7 \mathrm{~mm})$ in length and $8.6 \pm 0.7 \mathrm{~mm}(n=250)$ in maximum width. The egg capsules were attached in rows parallel to the internal lip of the aperture of the shell, extending outwards over the callus. Thus, the egg capsules from an incomplete mass were always situated on the callus close to the columella, and the outer capsules were thus the last to be laid; we photographed one oviposition event in situ (Fig. 3C). All capsules were sculptured on the side facing the animal's body, while the other side was smooth (Fig. 3E). Reproductive parameters are summarized in Table 3.

No linear relationship was found between TSL and the number of egg capsules attached to the shell $(F=1.82 ; P=$ $0.19 ; n=50)$. As a result, the linear regression of $\mathrm{BC}$ on number of egg capsules could not be calculated; instead we analysed the relation of WBM to the number of egg capsules, but no significant relationship was found $(F=1.304 ; P=0.37 ; n=29$ ).

\section{Development}

The mean egg diameter prior to cleavage was $227.5 \pm 13.5 \mu \mathrm{m}$ $($ mean $\pm \mathrm{SD})(n=2500)$. Each egg capsule contained $3101 \pm$ 494 eggs (range $=2005-4119 ; n=50$ from 10 females) (Fig. 5A). A few of the eggs developed completely and hatched as miniature adults. These eggs followed a typical holoblastic spiralian division. A conspicuous polar body appeared before the first cellular division and a short morula stage was observed (Fig. 5B-D); gastrula and 'trochophore' stages were not observed. During the 'veliger' stage the embryo began ingesting the nurse eggs, which were manipulated with ciliated velar lobes before passing whole and into the oesophagus (Fig. 5E, F). The eggs were found intact in the stomach, which is a blind sac (Fig. 6A). Each embryo appeared to ingest as many eggs as possible while they were available and after a long period of egg ingestion (Table 1) their guts were filled with $570 \pm 199$ eggs. The digestion of the eggs occurred at the 

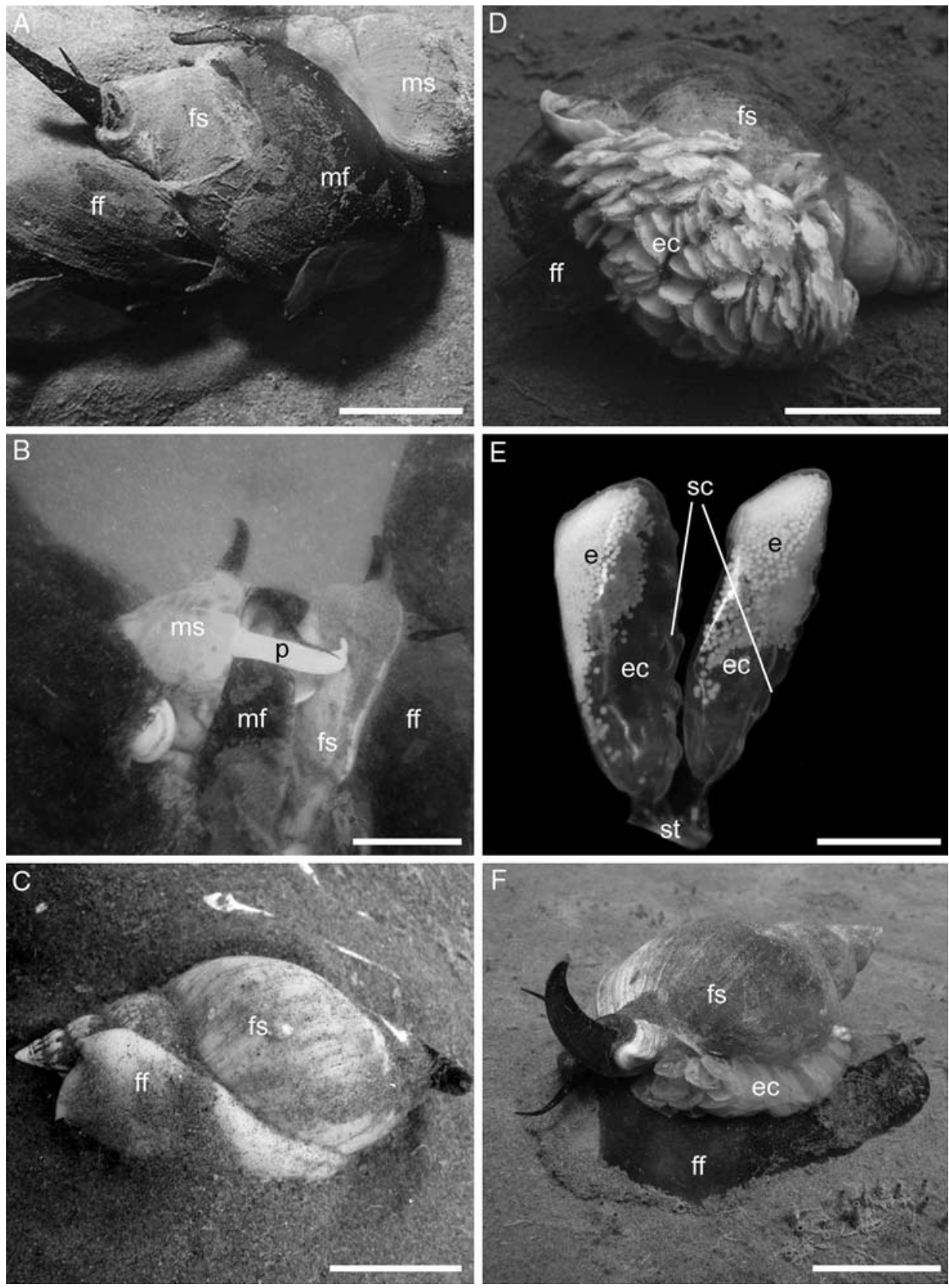

Figure 3. Mating and spawn of Buccinanops cochlidium. A, B. Pair of gastropods as observed in the field. A. Male's foot applied to shell of female. B. Pair separated; male's elongated white penis is visible. C. Female while spawning, in dorsal view. D. Female with a complete spawn. E. Detail of egg capsule shape and ornamentation. F. Crawling female with the residual egg capsules completely empty. Abbreviations: e, egg; ec, egg capsule; $\mathrm{ff}$, female foot; fs, female shell; $\mathrm{mf}$, male foot; ms, male shell; p, penis; sc, sculpture; st, stalk. Scale bars: $\mathbf{A}-\mathbf{D}, \mathbf{F}=3 \mathrm{~cm} ; \mathbf{E}=0.5 \mathrm{~cm}$.

same time that a translucent shell matrix developed (Fig. 6B). Growth and coiling of the whitish shell occurred as the foot developed and the velum disappeared (Fig. 6C, D). The crawling juvenile remained inside the egg capsule until the shell apex (a region occupied by the residual stomach sac) was closed. The shell was coloured with two purple bands, typical of the genus (Fig. 6E, F).

Between one and 20 embryos hatched per egg capsule $(5.4 \pm 2.5 ; n=172)$ with a mean shell length of $4.0 \pm 0.6 \mathrm{~mm}$ $(2.4-7.0 ; n=626)$. The juveniles emerged from the capsule through an apical ridge opposite to the stalk (Fig. 6E); this opening is not a plug or operculum as in other caenogastropods. The developmental stages within the egg capsules of each female were always synchronous.

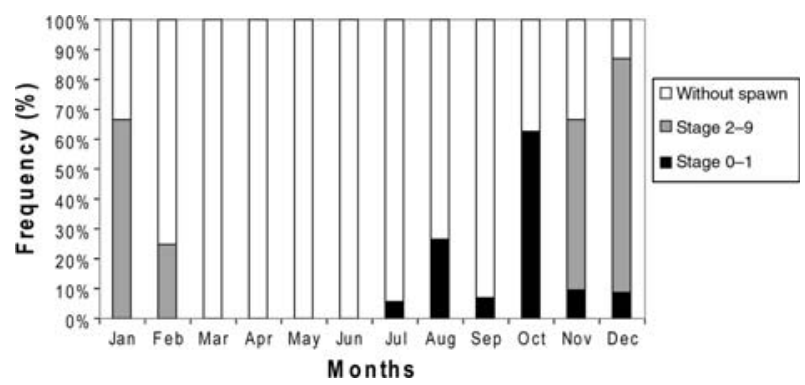

Figure 4. Monthly proportion of females of Buccinanops cochlidium carrying egg capsules in stage $0-1$ (black bars) or later stages (gray bars), and without egg capsules (unshaded). 
Table 3. Reproductive parameters of Buccinanops cochlidium.

\begin{tabular}{|c|c|c|c|c|c|}
\hline $\begin{array}{l}\text { Spawning females } \\
\text { shell length }(\mathrm{mm})\end{array}$ & Egg capsules per female & Eggs per capsule & Egg diameter $(\mu \mathrm{m})$ & Hatchlings per capsule & Hatchling length (mm) \\
\hline $\begin{array}{l}90.8 \pm 4.8 \\
\quad(80-102) n=50\end{array}$ & $\begin{array}{l}142.2 \pm 30.1 \\
\quad(80-238) n=50\end{array}$ & $\begin{array}{l}3101.5 \pm 494.3 \\
\quad(2005-3898) n=50\end{array}$ & $\begin{array}{l}227.5 \pm 13.5 \\
\quad(160-320) n=2500\end{array}$ & $\begin{array}{l}5.4 \pm 2.5 \\
\quad(1-20) n=172\end{array}$ & $\begin{array}{l}4.0 \pm 0.6 \\
\quad(2.4-7.00) n=626\end{array}$ \\
\hline
\end{tabular}

Values represent mean size $\pm S D$ and range (brackets).
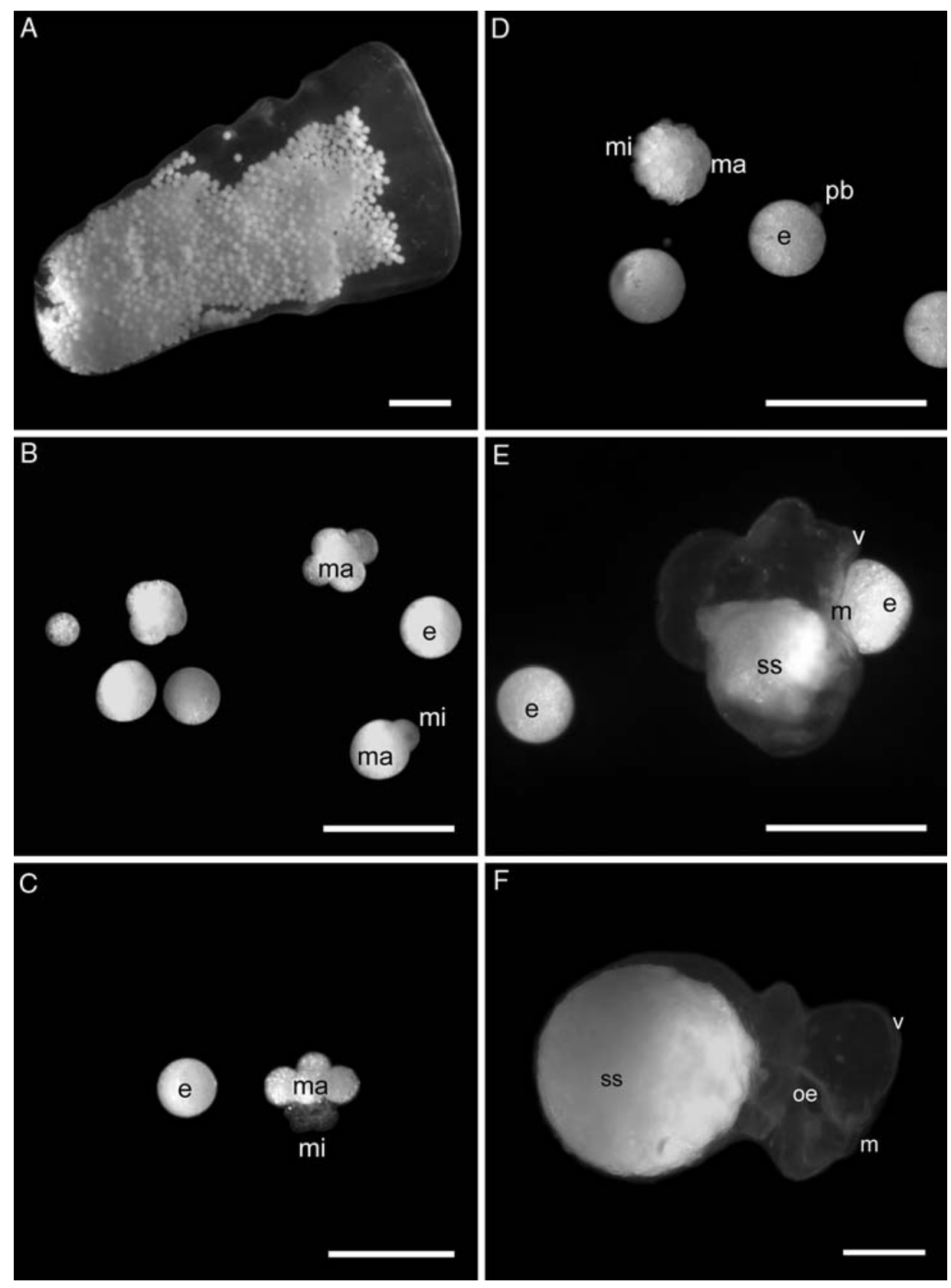

Figure 5. Embryological development of Buccinanops cochlidium. A. Egg capsule in stage 0. B. Eggs and cellular cleavage stage. C. 16-Cell stage. D. Morula. E. 'Veliger' stage embryo eating an egg. F. 'Veliger' stage embryo full of eggs with velum and oesophagus visible by transparency. Abbreviations: e, egg; m, mouth; ma, macromeres; mi, micromeres; oe, oesophagus; pl, polar body; ss, stomach sac; v, velum. Scale bars: $\mathbf{A}=$ $2 \mathrm{~mm} ; \mathbf{B}-\mathbf{F}=500 \mu \mathrm{m}$.

The relationship between the number of embryos per egg capsule and the MHSL was highly significant $(F=403.7 ; P<$ $0.0001 ; r^{2}=0.5132 ; n=385$ ) (Fig. 7).

\section{Aquarium observations}

Observations from the aquaria showed that the developmental time ranged between 106 and 136 days, mostly represented 

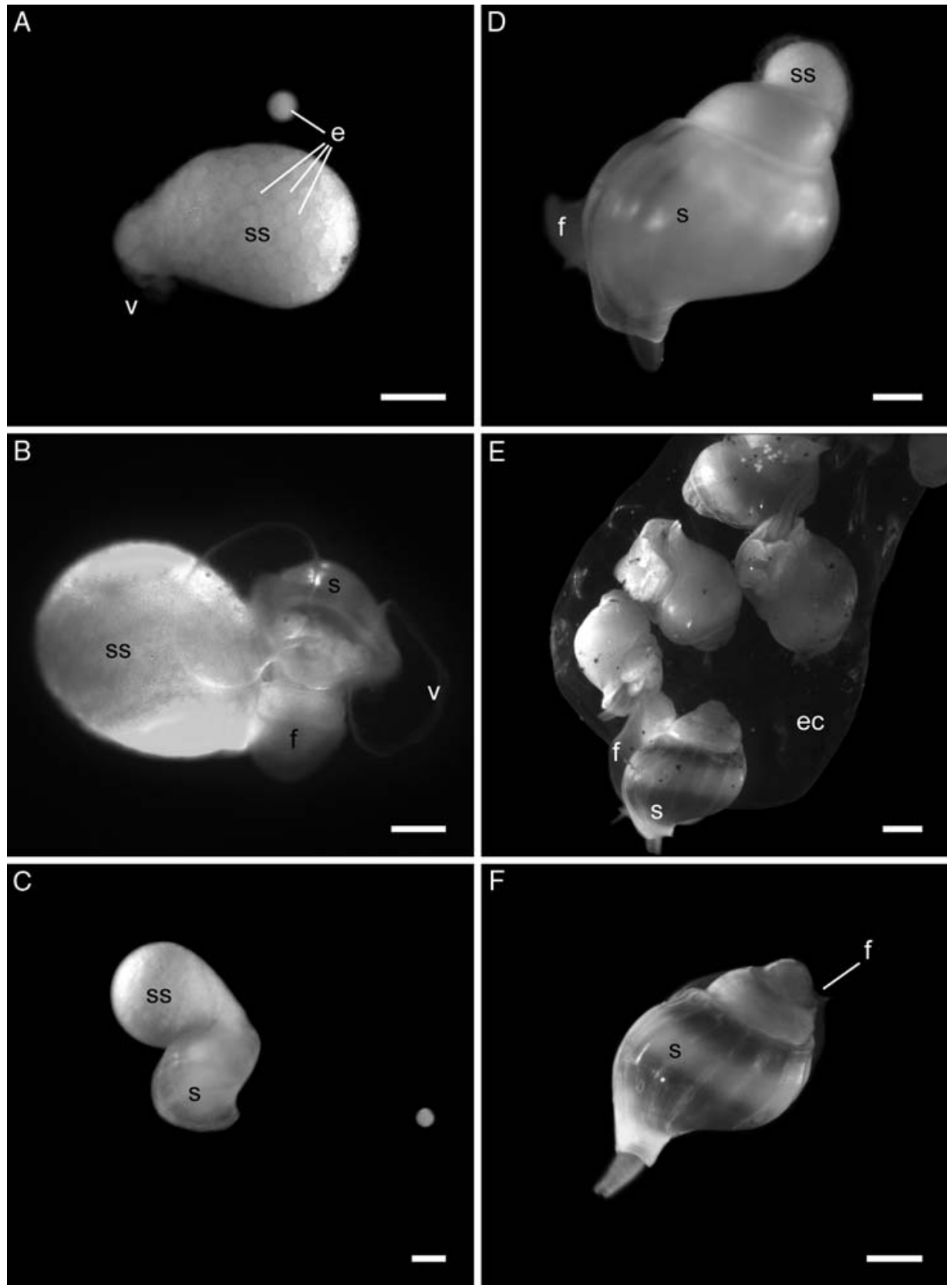

Figure 6. Embryological development of Buccinanops cochlidium (continued). A. 'Veliger' stage embryo full of entire eggs. B. Late 'veliger' stage embryo with developing shell and foot. C. Coiled-shell embryo. D. Pre-hatching stage with shell almost completely closed. E. Juveniles hatching from capsule. F. Hatchling. Abbreviations: e, egg; ec, egg capsule; f, foot; s, shell; ss, stomach sac; v, velum. Scale bars: $\mathbf{A}-\mathbf{F}=500 \mu \mathrm{m}$.

by the ingesting stage and the coiling (shell growth) stage (Table 1).

\section{DISCUSSION}

The studied population of Buccinanops cochlidium showed one reproductive cycle during the year. After mating (starting in March), oviposition began in July and continued until November, when both mating and oviposition stopped; intracapsular development then continued and hatchlings emerged in February. Mating occurred mainly during autumn and winter $\left(18-10^{\circ} \mathrm{C}\right)$, while oviposition stopped when water temperature was lowest, and development occurred with increasing water temperature during spring and summer (10$\left.18^{\circ} \mathrm{G}\right)$. Spermatozoa were present in the bursa copulatrix of females during the entire mating period, but not from one reproductive season to the next.

Mating has not been described previously for Buccinanops species. The copulatory mode described here resembles that described for Bullia by Brown (1982), except that no group aggregation was observed in the present study.

The minimum size of females carrying egg capsules was $80 \mathrm{~mm}$ and represents a measure of sexual maturity. All individuals carrying egg capsules were females. The act of oviposition was observed in the field only once; the semi-buried female placed the gonopore in contact with the callus of the shell, confirming our assumption that each female attached their own egg capsules to their own shell. This assumption is also supported by the synchronous development of each egg capsule mass. A proper management of this species as a fishery 


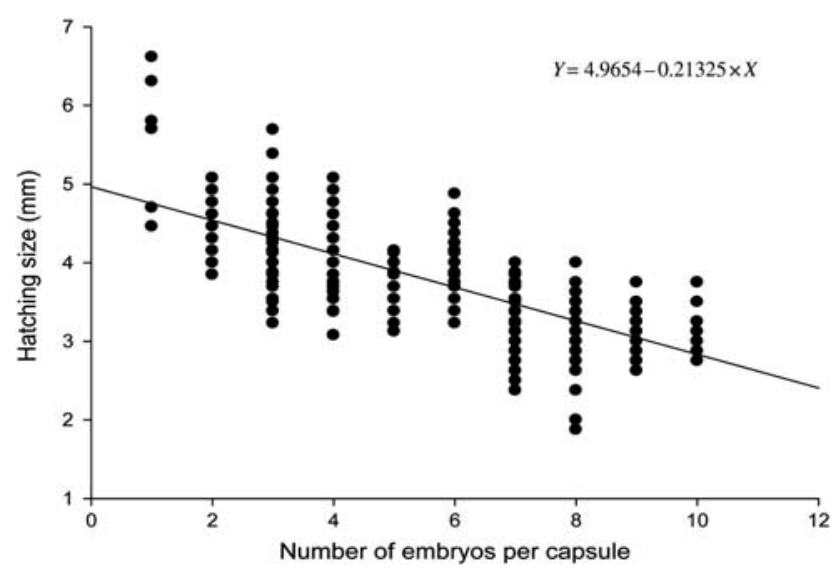

Figure 7. Mean size of hatchlings mean size vs number of hatchlings per egg capsule of Buccinanops cochlidium.

resource should exclude snails carrying egg capsules and establish the minimum oviposition size as the minimum for capture.

The embryos of $B$. cochlidium complete intracapsular development under aquarium conditions in 121 days. This developmental time may be overestimated because the aquarium water temperature does not increase with time, as it does in natural conditions. On the other hand, this period of approximately four months coincides with the time elapsed in nature between the peak of oviposition (October) and the peak of hatching (February). Each spawn represents a huge laying event, with a mean fecundity per female of 450,000 eggs (mean diameter $=227 \mu \mathrm{m}$ ) and more than 800 hatchlings of $4.0 \mathrm{~mm}$ shell length. These numbers are comparable with the 490,000 eggs laid by Buccinum isaotakii in Japanese waters, in which the number of hatching embryos is 8,000 , with a shell length of $2.5 \mathrm{~mm}$ (Ilano, Fujinaga \& Nakao, 2004).

The number of egg capsules attached to the shell shows no significant relationship to shell size (TSL) or body mass (WBM). Possibly, the WBM or TSL could be more closely related to the total investment made by each female (i.e. a combination of the number of egg capsules and the number of eggs in) (Chaparro et al., 1999; Ilano et al., 2004). Furthermore, reproductive effort may vary throughout life (Clutton-Brock, 1991), so that females of the same size or weight class but of different ages may show different reproductive investment.

The embryos within an egg capsule do not start to develop exactly simultaneously, although they arrive simultaneously at the hatching stage, but with varying shell sizes (dependent upon the amount of nurse eggs ingested). The regression of MHSL on the number of embryos per capsule was significant, but explained only $51 \%$ of the variance, suggesting the influence of other variables (e.g. amount of nurse eggs).

The developmental time of B. cochlidium can be compared with that of Buccinum undatum and Buccinum cyaneum from temperate waters, with a complete intracapsular developmental period of up to nine months (Miloslavich, 1996). Buccinid species with nurse eggs that inhabit tropical waters show shorter developmental times, e.g. three months in Fusinus closter and seven weeks in Fasciolaria tulipa hollisteri (with shelled veliger hatchlings) (Miloslavich, 1996).

The intracapsular 'veliger' full of nurse eggs was incorrectly interpreted as an 'egg package' within a membrane by Penchaszadeh (1971a, b, 1973), based on the work of Ansell \& Trevallion (1970) and others (Crichton, 1943; Barnard, 1958). These 'egg packages' are, in fact, the result of competition between embryos for a limited amount of food. The intracapsular 'veliger' stage embryos of $B$. cochlidium ingested and stored hundreds of entire nurse eggs. A discussion on the advantages of ingesting more than an average number of nurse eggs has been given by Spight (1976). The variety of hatching sizes per egg capsule and the increase of the mean hatching size when there is a lower number of embryos per capsule, are evidence for this competition in B. cochlidium (Pechenik, 1986; Chaparro et al., 1999). The nassariid genus Bullia includes species such as Bullia digitalis (Brown, 1971) whose ingestion mode resembles that of $B$. cochlidium, while in others, such as Bullia melanoides and Bullia tenuis, there is evidence of embryonic cannibalism (Ansell \& Trevallion, 1970; Brown, 1985).

\section{ACKNOWLEDGEMENTS}

This research was partially supported by projects CONICET PIP-5301, PICTR-01869 and UBACyT X-171, and Lic. Averbuj's PhD Fellowship by CONICET. We express our special thanks to Eugenia Zavattieri and Oscar Wheeler, and to all colleagues who participated in sample collection. Special thanks are given to those who provided preliminary comments on the manuscript (Dr Bigatti, Dr Graham Chafe, Dr Sophie Pan, Lic. Marzinelli, Lic. Bulit and Lic. Maru Vigna). All research work including sampling and experiments comply with current Argentine laws.

\section{REFERENGES}

ANSELL, A.D. \& TREVALLION, A. 1970. Brood protection in the stenoglossan gastropod Bullia melanoides (Deshayes). Fournal of Natural History, 4: 369-374.

BARNARD, K.H. 1958. Contributions to the knowledge of South African marine Mollusca. Part 1. Gastropoda: Prosobranchiata: Toxoglossa. Annals of the South African Museum, 44: 73-163.

BigatTi, G., PRimost, M.A., CLEDÓN, M., AVERBUJ, A., THEOBALD, N, GERWINSKI, A., ARNTZ, W., MORRICONI, E. \& PENCHASZADEH, P.E. 2009. Contamination by TBT and imposex biomonitoring along $4700 \mathrm{~km}$ of Argentinean shoreline (SW Atlantic: from $38^{\circ} \mathrm{S}$ to $54^{\circ} \mathrm{S}$ ). Marine Pollution Bulletin, 58: 695-701.

BORZONE, G.A. 1995. Ovicápsulas de prosobranquios (Mollusca: Gastropoda) de una playa arenosa expuesta del sur de Brasil. Iheringia, Série Zoologia, 79: 47-58.

BROWN, A.C. 1971. The ecology of the sandy beaches of the Cape Peninsula, South Africa. Part 2: the mode of life of Bullia (Gastropod: Prosobranchiata). Transaction of the Royal Society of South Africa, 39: 281-320.

BROWN, A.C. 1982. The biology of sandy-beach whelks of the genus Bullia (Nassariidae). Oceanography and Marine Biology, Annual Review, 20: $309-361$

BROWN, A.C. 1985. Egg capsules and young of Bullia tenuis (Nassariidae). Fournal of Molluscan Studies, 51: 100

CHAPARRO, O.R., OYARZUN, R.F., VERGARA, A.M. \& THOMPSON, R.J. 1999. Energy investment in nurse eggs and egg capsules in Crepidula dilatata Lamarck (Gastropoda, Calyptraeidae) and its influence on the hatching size of the juvenile. Fournal of Experimental Marine Biology and Ecology, 232: 261-274.

CIOCCO, N.F. 1999. Relevamiento y sistematización de información sobre mariscos de interés para la pesca artesanal en las costas de Chubut. Consejo Federal de Inversiones-Pcia. del Chubut.

CLUTTON-BROCK, T.H. 1991. The evolution of parental care. Cambridge University Press.

CRICHTON, M.D. 1943. Some notes on the Madras Bullia. Fournal of Molluscan Studies, 25: 143-146.

FIORONI, P. 1967. Quelques aspects de ĺmbryogenèse des prosobranches (Mollusca, Gastropoda). Vie et Milieu (Serie A, Biologie Marine), 18: 153-174.

FRETTER, V. \& GRAHAM, A. 1994. British prosobranch molluscs: their functional anatomy and ecology. Ray Society, London. 


\section{A. AVERBUJ AND P. E. PENCHASZADEH}

GOLDBERG, R., AVERBUJ, A., CLEDON, M., LUZZATTO, D. \& NUDELMAN, N.S. 2004. Search for triorganotins along the Mar del Plata (Argentina) marine coast: finding of tributyltin in egg capsules of a snail Adelomelon brasiliana (Lamarck, 1822) population showing imposex effects. Applied Organometalic Chemistry, 18: 117-123.

HARGITAI, R., TOROK, J., TOTH, L., HEGYI, G., ROZIVALL, V., SZIGETI, B. \& SZOLLOSI, E. 2005. Effects of environmental conditions and parental quality on inter- and intraclutch egg-size variation in the collared flycatcher (Ficedula albicollis). The Auk, 122: $509-522$.

ILANO, A.S., FUJINAGA, K. \& NAKAO, S. 2004. Mating, development and effects of female size on offspring number and size in the neogastropod Buccinum isaotakii (Kira, 1959). Fournal of Molluscan Studies, 70: 277-282.

MILOSLAVICH, P. 1996. Biochemical composition of prosobranch egg capsules. Fournal of Molluscan Studies, 62: 133-135.

MILOSLAVICH, P. 1999. Nutritional value of the intracapsular liquid of Engoniophos unicinctus Say, 1825 (Caenogastropoda: Buccinidae). Fournal of Molluscan Studies, 65: 502-503.

PASTORINO, G. 1993. The taxonomic status of Buccinanops d'Orbigny, 1841 (Gastropoda: Nassariidae). Veliger, 36: 160-165.

PECHENIK, J.A. 1975. The escape of veligers from egg capsules of Nassarius obsoletus and Nassarius trivittatus (Gastropoda, Prosobranchia). Biological Bulletin, 149: 580-589.

PECHENIK, J.A. 1986. The encapsulation of eggs and embryos by molluscs: an overview. American Malacological Bulletin, 4: 165-172.

PENCHASZADEH, P.E. 1971a. Aspectos de la embriogenesis de algunos gasterópodos del género Buccinanops d'Orbigny, 1841 (Gastropoda, Prosobranchiata, Buccinidae). Physis, 30: 475-482.
PENCHASZADEH, P.E. 1971b. Observaciones sobre la reproducción y Ecología de Dorsanum moniliferum (Valenciennes, 1834) (Gastropoda: Buccinidae) en la región de Mar del Plata. Neotropica, 17: $49-54$

PENCHASZADEH, P.E. 1973. Nuevas observaciones sobre la reproducción de Buccinanops gradatum (Deshayes, 1844) (Gastropoda: Prosobranchiata, Dorsaninae). Physis A, 32: 15-18.

PENCHASZADEH, P.E. 1976. Reproducción de Gasterópodos prosobranquios del Atlántico suroccidental. El género Trophon. Physis, 35: 69-76.

PENCHASZADEH, P.E. \& PAREDES, C. 1996. Observations on the spawn of Fasciolaria tulipa hollisteri (Weisbord 1962) (Gastropoda: Prosobranchia) from the Southern Caribbean. Malacological Review, 6: $9-14$.

PENCHASZADEH, P.E. \& RINCÓN, A. 1996. Egg capsules and development of Prunum prunum (Gmelin, 1791) (Prosobranchia: Marginellidae) from the Venezuelan Caribbean. Veliger, 39: 83-86.

PENCHASZADEH, P.E., AVERBUJ, A. \& CLEDÓN, M. 2001. Imposex in gastropods from Argentina (South-Western Atlantic). Marine Pollution Bulletin, 42: 790-791.

RIOS, E.C. 1994. Seashells of Brazil. Rio Grande, Editora da Fundaçao Universidade do Rio Grande.

SPIGHT, T.M. 1976. Hatching size and the distribution of nurse eggs among prosobranch embryos. Biological Bulletin, 150: $491-499$.

Van Den BIgGelaAR, J.A.M. \& HASZPRUNAR, G. 2003. Cleavage patterns and mesentoblast formation in the Gastropoda: an evolutionary perspective. Evolution, 50: 1520-1540. 